\title{
Clostridioides difficile in national food surveillance, Slovenia, 2015 to 2017
}

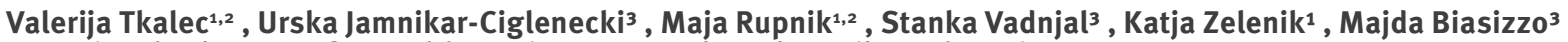

1. National Laboratory for Health, Environment and Food, Maribor, Slovenia

2. Faculty of Medicine, University of Maribor, Maribor, Slovenia

3. Institute of Food Safety, Feed and Environment, Veterinary Faculty, University of Ljubljana, Ljubljana, Slovenia

Correspondence: Maja Rupnik (maja.rupnik@nlzoh.si)

Background: Clostridioides difficile is an important human and animal intestinal pathogen. Because of increasing indications of an association between $C$. difficile and food, in 2015, the Administration of the Republic of Slovenia for Food Safety, Veterinary Sector and Plant Protection (UVHVVR) included $C$. difficile in its national food surveillance. Aim: We aim to report the results and experience with a nationwide and longterm testing of food for $C$. difficile as a part of a regular national food surveillance programme. Methods: Retail minced meat and meat preparations (beef, pork and poultry) were sampled within a three-year period, 2015 to 2017 . Selected raw retail vegetables, leaf salads and root vegetables, and ready-to-eat salads were only sampled during 2016 and 2017. Seafood was only sampled in 2017. Results: Altogether, 434 samples were tested, with 12 of 336 (3.6\%) meat samples and 6 of $98(6.1 \%)$ raw vegetables contaminated with $C$. difficile. Twelve of 18 recovered food isolates were toxigenic (toxinotypes 0, III, V, XII). The isolates belonged to 13 different PCR ribotypes, 001 being most common (5 isolates). Several food types with an increased potential of being contaminated with $C$. difficile were detected by surveillance. Conclusion: The three-year $C$. difficile testing within the national food surveillance revealed a low proportion of $C$. difficile-contaminated food and high genotype variability. Because the risk of $C$. difficile infection associated with $C$. difficile-contaminated food is unknown, no measures were recommended in the case of positive results.

\section{Introduction}

Clostridioides difficile is an important cause of intestinal infections in humans. The global rates of $C$. difficile infections (CDI) have increased considerably over the past two decades [1-4]. In Slovenia, the reporting of $C D I$ is obligatory. According to the report on infectious disease surveillance in Slovenia for the year 2017, provided by the National Institute for Public Health, the number of cases increased from 316 in the year 2013 to 665 in the year 2017 [5]. No community outbreaks were reported in Slovenia during this time and only a few outbreaks were reported in hospitals [6]. The reason for this increase is not completely clear, but could include improved reporting and changes in laboratory practice.

For more than a decade, the zoonotic potential and food-borne transmission of $C$. difficile have been hypothesised to contribute to its spread [7-11]. The zoonotic transmission is supported by the occurrence of $C$. difficile in animals, and the shared PCR ribotypes between humans and animals. A more precise wholegenome analysis has confirmed an overlap of genetically related strains between humans and animals [12-15].

Food studies have mainly focused on meat and meat products; however, raw and ready-to-eat vegetables, seafood and milk can also contain $C$. difficile $[10,11,16]$. Most of the reported prevalence rates vary from not detected to $12.5 \%$ in meat and $7.5 \%$ in vegetables $[10,11,17]$, but can rise above $50.0 \%$ in seafood and root vegetables [18-21]. As with animal strains, PCR ribotypes of food isolates can also overlap with human PCR ribotypes and can be genetically undistinguishable from human isolates by MLVA, a method with higher discriminatory power than PCR ribotyping [16].

Because of increasing indications of moderate to high rates of $C$. difficile contamination of certain food, in 2015, the Administration of the Republic of Slovenia for Food Safety, Veterinary Sector and Plant Protection (Uprava za varno hrano, veterinarstvo in varstvo rastlin (UVHVVR)) included $C$. difficile in the national surveillance programme of raw meats. In 2016, the $C$. difficile surveillance was expanded to selected vegetables. The objective was to determine the burden of $C$. difficile in retail food in Slovenia based on systematic data collection and analysis. Here we present the 
TABLE 1

Overview of the national food surveillance sampling plan and the number of samples tested for Clostridioides difficile, Slovenia, 2015-2017

\begin{tabular}{|c|c|c|c|c|c|c|c|}
\hline \multirow[b]{2}{*}{ Food type } & \multirow[b]{2}{*}{ Description } & \multicolumn{2}{|c|}{2015} & \multicolumn{2}{|c|}{2016} & \multicolumn{2}{|c|}{2017} \\
\hline & & $\begin{array}{l}\text { All tested } \\
\text { samples } \\
\text { (n) }\end{array}$ & $\begin{array}{l}\text { Samples } \\
\text { tested for } \\
\text { C. difficile (n) }\end{array}$ & $\begin{array}{l}\text { All tested } \\
\text { samples } \\
\text { (n) }\end{array}$ & $\begin{array}{l}\text { Samples } \\
\text { tested for } \\
\text { C. difficile (n) }\end{array}$ & $\begin{array}{l}\text { All tested } \\
\text { samples } \\
(\mathrm{n})\end{array}$ & $\begin{array}{l}\text { Samples } \\
\text { tested for } \\
\text { C. difficile (n) }\end{array}$ \\
\hline \multicolumn{8}{|l|}{ Animal origin } \\
\hline \multicolumn{2}{|l|}{ All types } & 345 & 119 & 363 & 130 & 462 & 87 \\
\hline Raw beef or/and pork & $\begin{array}{l}\text { Minced meat and meat } \\
\text { preparations }\end{array}$ & 60 & 59 & 60 & 60 & 60 & 20 \\
\hline Raw poultry meat & $\begin{array}{l}\text { Raw poultry meat and } \\
\text { meat preparations, ducks }\end{array}$ & 60 & 60 & 70 & 70 & 110 & 50 \\
\hline Seafood & $\begin{array}{l}\text { Live bivalve molluscs } \\
\text { (mussels, clams) and } \\
\text { cooked crustaceans }\end{array}$ & 10 & 0 & 21 & 0 & 22 & 17 \\
\hline $\begin{array}{l}\text { Ready-to-eat meat } \\
\text { products }\end{array}$ & $\begin{array}{l}\text { Salami and sausages } \\
\text { (fermented, dried, } \\
\text { smoked), minced lard, } \\
\text { other meat products }\end{array}$ & 70 & 0 & 60 & 0 & 50 & 0 \\
\hline Milk and milk products & $\begin{array}{l}\text { Raw milk and cheese } \\
\text { (bovine, ovine, goat) }\end{array}$ & 90 & 0 & 85 & 0 & 85 & 0 \\
\hline Fish and fish products & $\begin{array}{l}\text { Fish pate; smoked, canned } \\
\text { and raw fish }\end{array}$ & 55 & o & 67 & 0 & 35 & 0 \\
\hline \multicolumn{2}{|l|}{ Eggs } & o & 0 & 0 & 0 & 100 & 0 \\
\hline \multicolumn{8}{|l|}{ Non-animal origin ${ }^{a}$} \\
\hline \multicolumn{2}{|l|}{ All types } & 335 & NA & 335 & 48 & 355 & 50 \\
\hline \multirow{3}{*}{ Vegetables } & $\begin{array}{c}\text { Ready-to-eat salads } \\
\text { (from mixed vegetables, } \\
\text { leaf salads, tomatoes, } \\
\text { cucumbers) }\end{array}$ & 70 & NA & 70 & 28 & 60 & 30 \\
\hline & $\begin{array}{c}\text { Raw vegetables (leaf } \\
\text { salads, root vegetables) }\end{array}$ & 0 & NA & 20 & 20 & 20 & 20 \\
\hline & Sprouts, sprout seeds & 15 & NA & 20 & 0 & 15 & 0 \\
\hline \multirow{2}{*}{ Fruit } & Ready-to-eat fruit & 10 & NA & 20 & 0 & 20 & 0 \\
\hline & Berries & 10 & NA & 10 & 0 & 10 & 0 \\
\hline \multicolumn{2}{|l|}{ Nuts } & 20 & NA & 0 & 0 & 40 & 0 \\
\hline \multicolumn{2}{|l|}{ Ice cream } & 30 & NA & 50 & 0 & 20 & 0 \\
\hline \multicolumn{2}{|l|}{ Herbs, spices } & 10 & NA & 25 & 0 & 30 & 0 \\
\hline \multirow{3}{*}{ Ready-to-eat food } & Confectionery & 60 & NA & 40 & 0 & 40 & 0 \\
\hline & Sandwiches & 40 & NA & 40 & o & 30 & 0 \\
\hline & Other ready-to-eat food & 70 & NA & 40 & 0 & 70 & 0 \\
\hline
\end{tabular}

NA: not applicable.

a The national $C$. difficile surveillance programme of vegetables started in 2016.

results of $C$. difficile detection in Slovenian retail food based on 3 years of national food surveillance.

\section{Methods}

\section{Participating laboratories}

Two different institutions provide the sampling and microbiological analysis of food samples in national food surveillance program. Sampling and analysis of meat and seafood is performed by the National Veterinary Institute, which operates under the auspices of the Veterinary Faculty, University of Ljubljana. Food of non-animal origin is sampled and analysed by the National Laboratory for Health, Environment and Food $(\mathrm{NLZOH})$. Both institutions followed the annual sampling instructions released by the UVHVVR. Results are reported to UVHVVR at the end of yearly surveillance and included in its annual report.

\section{Sampling}

Different types of raw meat, including bovine or/and pork minced meat and meat preparations, poultry meat and poultry meat preparations were collected at food markets and grocery stores in all Slovenian regions from April to December 2015 and from March to December in both 2016 and 2017. Meat preparations are defined in European Union regulation (EC) $853 / 2004$ as fresh meat, including meat that has been reduced to fragments, which has had foodstuffs, seasonings or additives added to it or which has undergone processes insufficient to modify the internal muscle fibre structure of the meat and thus to eliminate 


$$
\text { | }
$$




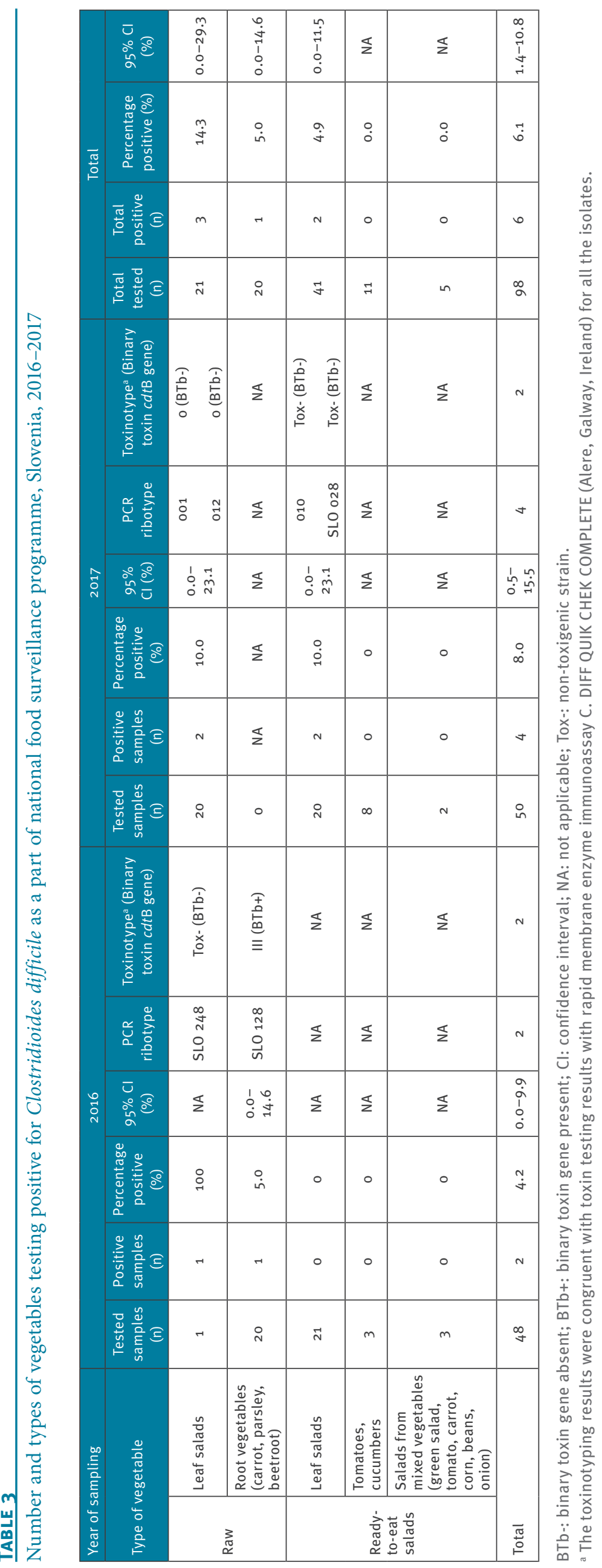




\section{TABLE 4}

Comparison of Clostridioides. difficile PCR ribotypes detected in the national food surveillance to strains isolated in Slovenia from different reservoirs ${ }^{\mathrm{a}}, 2008-2017$

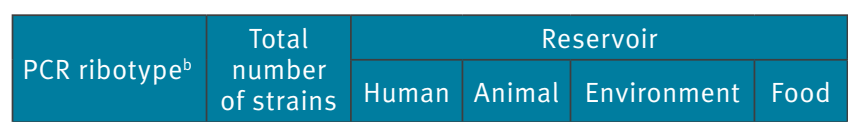

\begin{tabular}{|l|c|c|c|c|c|}
\hline 001 & 217 & 187 & 16 & 14 & 7 \\
\hline 010 & 187 & 62 & 22 & 103 & 0 \\
\hline 012 & 69 & 58 & 2 & 9 & 2 \\
\hline $014 / 020$ & 826 & 556 & 72 & 198 & 17 \\
\hline 015 & 46 & 36 & 1 & 9 & 0 \\
\hline 078 & 45 & 28 & 5 & 12 & 0 \\
\hline 087 & 36 & 36 & 0 & 0 & 0 \\
\hline SLO 028 & 5 & 4 & 0 & 1 & 0 \\
\hline SLO 057 & 35 & 6 & 13 & 16 & 2 \\
\hline SLO 128 & 1 & 1 & 0 & 0 & 0 \\
\hline SLO 248 & 3 & 1 & 0 & 2 & 0 \\
\hline
\end{tabular}

a The strains presented in the table were isolated from 2008 to the end of the current surveillance and are part of our strain collection (data not shown).

b Two PCR ribotypes are not included in the table: SLO 283 was unique to our strain collection while for SLO 052, a single strain was present in the collection and originated from Croatia.

the characteristics of fresh meat [22]. Seafood was only sampled from March to December 2017 (excluding October).

Like retail meat samples, vegetables were sampled systematically in all Slovenian regions, but only from March to December in 2016 and 2017 (excluding April 2016 and November 2017). Samples were obtained from various retailers, including restaurants, food markets, grocery stores and supermarkets.

Information on sampling location and date was recorded for each collected sample.

A total of 336 samples of meat (raw and minced), 319 meat preparations and 17 seafood were tested between 2015 and 2017, with 4 to 24 samples tested per month. Samples were categorised as raw poultry meat $(n=60)$, meat preparations from poultry $(n=120)$, minced pork and/or beef meat $(n=60)$, meat preparations from pork and/or beef meat $(n=79)$, shrimps $(n=9)$ and bivalve molluscs $(n=8)$. (Table 1$)$.

A total of 98 vegetable samples were collected, with one to 13 samples tested per month. Samples included different types of raw green leafy salads $(n=21$; green lettuce $(n=20)$ and lamb's lettuce $(n=1))$, ready-to-eat salads $(n=57)$ and root vegetables $(n=20$; carrots, parsley, beetroot). Ready-to-eat salads were those made of leafy green lettuce $(n=41$; green lettuce, radicchio, cabbage, rucola), cut cucumbers $(n=3)$, cut tomatoes $(n=7)$ or ready-to-eat salad combinations of two or more different kinds of fresh produce $(n=6$; green lettuce, cabbage, spinach, tomatoes, cucumbers, beans, corn, carrots, onions) (Table 1).

\section{Origins of samples}

C. difficile was found in our previous study on imported retail potatoes, indicating a potential way for $C$. difficile to spread between countries [21]. For this reason, information of food origin was also included in the analysis of the samples from the national food surveillance.

Of 319 meat and meat preparation samples, 266 were labelled 'made in Slovenia' (70.8\%), 21 'made in Austria' (6.6\%), 11 'made in Croatia' (3.4\%), nine 'made in Germany' (2.8\%), one 'made in Hungary” (0.3\%) and one 'made in Denmark' (0.3\%). A further five samples included ingredients from more than one country while another five had no information on origin available. Samples of shrimps $(n=9)$ originated from Lithuania, Denmark, Ecuador and the Czech Republic, while all samples of bivalve molluscs $(n=8)$ originated from Slovenia.

Of the 98 vegetable products, most $(n=81 ; 82.7 \%)$ were labelled 'made in Slovenia'. Sixteen were made in Italy $(n=8)$ or other European countries (Austria $(n=1)$, Croatia $(n=1)$, Hungary $(n=1)$, Germany $(n=1)$, the Netherlands $(n=1)$, Poland $(n=2)$, Spain $(n=1))$. No information on processing or origin was available for one sample.

\section{Isolation of Clostridioides difficile}

Retail meat samples and seafood were analysed by the microbiological laboratory of the Institute of Food Safety, Feed and Environment, which is a part of the National Veterinary Institute. The isolation protocol for meat samples was previously established and evaluated by Biasizzo et al., 2018 [23], where samples spiked with 1,000, 100 and 10 CFU per sample were tested and $100 \%$ sensitivity was determined for all spiked samples.

Cycloserine cefoxitin fructose broth $(90 \mathrm{ml}$ ) supplemented with taurocholic acid and lysozyme (TCCFB + L; prepared according to Biasizzo et al.) was added to 10 $\mathrm{g}$ of each meat sample in a sterile plastic blender bag and homogenised in a peristaltic blender (BagMixer, Interscience, St Nom la Bretèche, France) for $1 \mathrm{~min}$. The samples were then incubated under anaerobic conditions at $37^{\circ} \mathrm{C}$ for 7 days. The enriched samples were tested for $C$. difficile by quantitative real-time PCR and plated after spore selection by ethanol treatment onto blood agar plates (blood agar supplemented with $5 \%$ defibrinated bovine blood), C. difficile agar base with added $C$. difficile selective supplement and $7 \%(\mathrm{v} / \mathrm{v})$ defibrinated horse blood ( cycloserine cefoxitin fructose agar (CCFA); all from Oxoid, Hampshire, United Kingdom (UK)) as previously described [23] and onto chromID C. difficile agar (bioMerieux, Lyon, France).

Retail vegetables were tested by NLZOH. Root and leafy vegetables were prepared differently, but for both, $25 \mathrm{~g}$ 
of the sample was analysed and the cultivation method was the same. Isolation was based on previously described cultivation method of Tkalec et al., 2019 [21] with detection threshold for root and leafy vegetables between 1 and 10 CFU per tested sample.

The recovery of $C$. difficile from root vegetables was assessed using sterile sponges (Polywipe, Medical Wire and Equipment (MWE), Corsham, UK), enrichment in BHIST broth (BHI supplemented with sodium taurocholate, yeast extract, L-cysteine, cycloserine and cefoxitin), spore selection by ethanol treatment and plating onto $C$. difficile selective agar (chromID C. difficile agar (bioMerieux)) [21]. Sampling with sponges is considerably more sensitive than using swabs [24] and can, together with enrichment step in cultivation, enable detection of 1 to 10 spores for swabbed potatoes [21].

The leafy vegetables were homogenised and incubated in blender bags (BagMixer, Interscience) in $200 \mathrm{ml}$ of BHIST. C. difficile was isolated after the spore selection and plating onto chromogenic agar plates (bioMerieux) as described for root vegetables.

Identification of all presumptive $C$. difficile colonies was confirmed by mass spectrometry (MALDI-TOF Biotyper System, Bruker Daltonik, Bremen, Germany).

\section{Molecular characterisation of Clostridioides difficile isolates}

All isolates were characterised by toxinotyping and $P C R$ ribotyping. Toxinotyping was done by PCR amplification and restriction analysis of $A_{3}$ and $B_{1}$ fragments of $t c d A$ and $t c d B$ genes as previously described by Rupnik and Janezic [25]. The binary toxin gene was detected by partial amplification of $c d t B$ [25].

$P C R$ ribotyping was performed with Janezic primers as described by Janezic [26]. Profiles obtained by agarosebased PCR ribotyping were analysed by BioNumerics software version 7.6 (Applied Maths NV, Sint-MartensLatem, Belgium) and compared with PCR ribotypes in our large PCR ribotype library that includes ca. 300 different PCR ribotypes, comprising isolates from Slovenia and abroad. Some of the reference library strains are representatives of internationally recognised ECDC/ Leeds PCR ribotypes. If there was no match with these reference strains, the ribotype has a local designation (SLO+number).

\section{Statistical analysis}

The data was analysed by R version 3.4.4 (R Foundation, Vienna, Austria). The analysis was performed for each categorical variable where the proportions were given. Proportions were compared using Fisher's exact test. Statistical significance was held at $p<0.05$.

\section{Results}

In years 2015, 2016 and 2017, a total of 345, 363 and 462 food samples of animal origin were tested, respectively (Table 1). Only a proportion of the samples was included in C. difficile testing: 119 (34.7\%) in 2015, 130 (35\%) in 2016 and 87 (18.8\%) in 2017. For food samples of non-animal origin, a total of 335 samples were tested in 2016 and 355 in 2017. Of those only a proportion of vegetables was tested for C. difficile: 48 (48.0\%) in 2016 and $50(62.5 \%)$ in 2017 (Table 1 ). This means that a total of 434 retail food samples collected as part of the national surveillance programme were tested for $C$. difficile. The overall prevalence of $C$. difficile in retail meat was $3.6 \%(12 / 336)$ (Table 2$)$ and in retail vegetables it was $6.1 \%(6 / 98)$ (Table 3$)$.

\section{Clostridioides difficile in retail meat and seafood}

In the year 2015 , three of 119 meat samples (2.5\%) tested positive for $C$. difficile, five of 130 meat samples (3.9\%) in 2016 and four of 87 meat/seafood samples (4.6\%) tested positive for C. difficile in 2017 (Table 2). Overall, C. difficile was isolated from 12 of 336 meat samples; five poultry meat preparations, three beef and/or pork meat preparations, three raw poultry meat and one bivalve molluscs. C. difficile was not detected in any of the 56 tested pork and/or beef minced meat samples. Of the $12 \mathrm{C}$. difficile-positive samples, 10 were made in Slovenia $3.8 \%$ of all tested samples made in Slovenia) and two were made in Austria (9.5\% of all tested samples made in Austria).

There was no significant statistical difference in $C$. difficile prevalence between different meat types/ categories or sampling locations (food markets vs grocery stores) ( $p>0.05)$.

\section{Clostridium difficile in retail fresh vegetables}

In 2016, two of 48 tested samples were $C$. difficile-positive and four of 50 samples tested positive in the year 2017 (Table 3). Collectively, C. difficile was isolated from six of $98(6.1 \%)$ tested samples, in particular from three of 21 raw leaf salads, one of 20 root vegetables and two of 57 ready-to-eat salads (Table 3). Comparison of $C$. difficile prevalence according to sample type (root, unprocessed salad, ready-to-eat salad) and location of sampling (supermarket, food market, farm, catering/restaurants) showed no significant statistical difference between the samples ( $p>0.05$ ).

Vegetables from three of six $C$. difficile-positive samples were grown in Italy, two in Slovenia and one in Poland. None of the positive vegetables shared sampling time point or location of sampling.

\section{PCR ribotypes and toxinotypes in retail food samples}

The 18 C. difficile isolates obtained from food belonged to 13 different PCR ribotypes (Tables 2 and 3). The most prevalent PCR ribotype was PCR ribotype $001(n=5)$, followed by $010(n=2)$. Both were detected in food 
of animal and non-animal origin. The other 11 PCR ribotypes were detected only once. One nontoxigenic PCR ribotype, SLO 283, was new to our PCR ribotype library. It was isolated from a beef/pork meat preparation of Slovenian origin.

Two thirds of the isolates were toxigenic $(n=12)$. Nine belonged to toxinotype $\mathrm{o}$ (BTb-) and the remaining three to toxinotypes III $(\mathrm{BTb}+), \mathrm{V}(\mathrm{BTb}+)$ and IX $(\mathrm{BTb}+)$ (Tables 2 and 3 ). One third of all isolates were non-toxigenic $(n=6)$, comprising three of six vegetable isolates (Table 3), two of 11 (meat isolates, as well as the isolate recovered from seafood (Table 2 ).

The majority of PCR ribotypes were already found in Slovenia, either in patients, animals, food or the environment (Table 4 ).

\section{Discussion}

C. difficile can be found in different types of food and the reported contamination rates vary between food types, countries and studies. The main novelty of this report is that it describes the first documented longterm, national $C$. difficile food surveillance performed thus far.

We found that the proportion of $C$. difficile positive meat and vegetable samples numerically increased every year. However, the number of tested samples was too low to speculate on any possible trends. The changes in samples sizes and produce types could have contributed to this observation. Except for vegetables in 2017 , the average annual positivity rate for food of animal or non-animal source was $4.6 \%$ or lower.

The proportion of meat samples positive for $C$. difficile detected during Slovenian food surveillance varied from $2.5 \%$ to $4.6 \%$ annually, and was $3.6 \%$ for entire 3-year interval. There are no published data available for Slovenia on meat contamination with $C$. difficile. In previous small sporadic pilot studies performed by $\mathrm{NLZOH}$ where 124 meat samples of pork, beef, sheep and poultry were tested, all were negative for $C$. difficile (Tkalec and Rupnik; data not shown). Therefore, it seems that the systematic sampling and optimised methodology [23] used in national surveillance contributed to better detection. Early studies about possible presence of $C$. difficile in food of animal origin from North America reported high contamination rates of meat and meat products $20 \%$ in beef and veal ground meat in Canada [27]; $14.3 \%$ to $62.5 \%$ depending on the meat sample type, in the US [28]). These high contamination rates have not been reported in subsequent European or other non-European studies $[8,10,11,17]$. In general, the meat testing results were comparable to other European countries reporting from none to $6.3 \%$ $[10,11,17]$ and to most of the recent reports from nonEuropean countries reporting from none to $12.5 \%$ contamination rate in different types of meat $[10,17,29]$. In our sample set, beef/pork minced meat were always negative for $C$. difficile; this was also the case in some reports from Switzerland and Austria [30,31]. However, other studies from Austria, Belgium, France and Sweden reported positivity rates from $1.9 \%$ to $4.7 \%[11,17]$. Poultry meat or meat preparations are not often included in the testing. In contrast to our finding of overall $4.4 \%(8 / 180)$ of $C$. difficile positive poultry samples, a $2.7 \%$ positivity rate in poultry meat was reported from the Netherlands while $C$. difficile was not detected in any poultry meat sample in Austria or Sweden [30,32].

The contamination rate of bivalve molluscs (5.9\%; $\mathrm{n}=1$ ) was determined on a small number of samples $(n=17)$. But similar percentages (3.9\%, 4.5\% and 4.8\%) were reported for Italy, Texas and Canada, respectively $[17,29]$. It seems that presence of $C$. difficile in mussels varies widely, as two other Italian studies found $49 \%$ (26 of 53 samples, and $75 \%$ (four of six samples) of mussels collected at farms or retailers in Naples, Italy to be positive for $C$. difficile $[18,19]$.

The proportion of $C$. difficile-positive vegetable samples $(6.1 \%)$ is comparable to the low to moderate percentages of contaminated vegetables and ready-to-eat salads reported by others [10,33-35]. Again, such comparisons are difficult not only because of the difference in methodology, but also because of heterogeneity of sampled vegetables. For this reason, the proportion of $C$. difficile-positive vegetable samples found during national $C$. difficile food surveillance cannot be directly compared with our previous study (9.4\%) [21]. Leaf salads were relatively often contaminated with $C$. difficile in Slovenian food surveillance $(14.3 \%$ of 21 samples). There is not much data on the testing of raw leaf salads, but a previous Slovenian survey found $8.8 \%$ of retail leaf salads positive for $C$. difficile [21], while a report from Iran found $5.7 \%$ positive and two studies from the US found $4.6 \%$ and $13.8 \%$ positive, respectively [29]. Ready-to-eat salads have been tested in France and Scotland, with 2.9 and $7.3 \%$ of samples positive, respectively $[33,36]$. However, the type of the ready-to-eat salads is vaguely described in most studies.

Of the root vegetables we tested (carrot, parsley and beetroot), only a single parsley sample was contaminated with $C$. difficile. An Australian study that tested organic root vegetables reported much higher positivity rates; $22.2 \%$ for beetroot, $5.6 \%$ for onions and $5.3 \%$ for carrots [20]. The vegetable reported by us and others to have a very high contamination rate (from $28.0 \%$ to up to $55.6 \%$ ) is the potato $[20,21]$, but potatoes were not included in the Slovenian food surveillance programme as these data were not available when the programme was started.

A large variety of PCR ribotypes and toxinotypes was found and it was slightly higher in vegetables than in meat. The six strains isolated from vegetables belonged to six different PCR ribotypes while the 12 strains isolated from meat belonged to nine different 
PCR ribotypes. Only ribotypes 001 and 010 were shared between meat/seafood and vegetables. All the strains of PCR ribotype 001 originated from Slovenian samples, while samples yielding strains of PCR ribotype 010 were from Italy (salad) and Slovenia (meat). Both PCR ribotypes 001 and 010 are rather diverse, and whole genome sequencing should be used to confirm the genetic (non)clonality. Of the 13 detected PCR ribotypes, only one was new to our PCR library. Some of the detected PCR ribotypes, such as 001, 010 and 078, are among the most prevalent in different human, animal and environmental studies from several countries, suggesting that certain PCR ribotypes are well adapted to survival in several different niches.

Some C. difficile-positive food samples in the food surveillance were of non-Slovenian origin. Another group of positive samples included foodstuffs that were composed of several ingredients, some of which had non-Slovenian origin. Positive samples or only their ingredients originated from Italy, Poland, Austria, Belgium and Lithuania. Therefore, as suggested earlier by the authors [21], food in general could possibly contribute to cross-border transmissions.

Theoretically, the $C$. difficile contamination sources of food could be very heterogeneous. For meat, the most direct way is faecal contamination during slaughtering, but post-production processing could also play a role. Despite a very low, close to zero, reported prevalence of $C$. difficile in poultry before slaughter by some groups $[8,37]$, higher contamination rates, up to $12.8 \%$, of raw poultry meat have been documented in North America $[37,38]$ and in our surveillance $(5.0 \%)$. This suggests a post-slaughter contamination source in the production line. A possible source for the contamination of both meat and vegetables could also be via contaminated hands during handling. The main sources of vegetable contamination are soil or indirect faecal contamination via irrigation or manuring [39]. Non-toxigenic strains are often found in rural soils [40] and were also commonly isolated from vegetables during our surveillance. This constant environmental exposure of vegetables to $C$. difficile spores is probably one of the reasons for higher contamination rates of vegetables compared to meat and meat products.

C. difficile food surveillance had several limitations. One of the limitations is that no baseline contamination rates were known for Slovenia. It is for this reason that testing for $C$. difficile was initially added for all samples of raw meat, meat preparations and raw vegetable planned to be sampled for other microbiological parameters in the surveillance programme. Another limitation is the difference in the methodology used by both institutions providing the testing. Institutions used their own optimised methods that differed in the quantity of the sample (higher for vegetables), enrichment medium and use of molecular methods for screening of positive enrichment cultures, used for meat only. This difference in the methodology could have contributed to the higher proportion of vegetable samples positive for $C$. difficile (6.1\%) compared with meat samples (3.6\%). However, both methods were previously shown to have detection limits of at least 10 spores per sample. Furthermore, because of different sampling procedures, different types of tested food, bias because of the low sample number and, more notably, the differences in detection methods [11], comparisons among published studies should be made cautiously.

One of the aims of the national food surveillance is consumer protection. However, the detection of $C$. difficile in food during the surveillance has not resulted in any recommended measures because the risk associated with contaminated $C$. difficile food is unknown. Given the low detected prevalence of $C$. difficile contaminated food samples, the food safety risks for the tested food types are likely very low. On the other hand, although the levels of food contamination with $C$. difficile spores are usually low [41], the constant exposure to the low spore levels in combination with a disrupted gut microbiota or immune incompetence could represent increased risk for $C$. difficile infection (CDI).

In summary, $C$. difficile testing within the national food surveillance programme over the course of 3 years revealed a low percentage of $C$. difficile-contaminated food and a high genotype variability. Surveillance detected that some food types included in regular food surveillance, such as meat preparations and leafy salads, are more likely to be contaminated. Because the risk associated with $C$. difficile contaminated food is unknown, no measures have been recommended in terms of any of the 18 foods positive for $C$. difficile.

\section{Acknowledgements}

The national surveillance was commissioned and financed by The Administration of the Republic of Slovenia for Food Safety, Veterinary Sector and Plant Protection (Uprava za varno hrano, veterinarstvo in varstvo rastlin (UVHVVR)).

\section{Conflict of interest}

None declared.

Authors' contributions

VT and KZ performed the vegetable testing; VT performed the typing; UJC, SV and MB performed the testing of meat and meat products; MR contributed to the comparative analysis and strain typing; VT and MR drafted the manuscript; all authors contributed to the preparation of the final version and approved the manuscript.

\section{References}

1. Lessa FC, Winston LG, McDonald LCEmerging Infections Program C. difficile Surveillance Team. Burden of Clostridium difficile infection in the United States. N Engl J Med. 2015;372(24):2369-70. PMID: 26061850 
2. van Dorp SM, Kinross P, Gastmeier P, Behnke M, Kola A, Delmée $M$, et al. Standardised surveillance of Clostridium difficile infection in European acute care hospitals: a pilot study, 2013. Euro Surveill. 2016;21(29):30293. https://doi. org/10.2807/1560-7917.ES.2016.21.29.30293 PMID: 27472820

3. Kola A, Wiuff C, Akerlund T, van Benthem BH, Coignard B, Lyytikäinen 0 , et al. Survey of Clostridium difficile infection surveillance systems in Europe, 2011. Euro Surveill. 2016;21(29):30291. https://doi.org/10.2807/1560-7917. ES.2016.21.29.30291 PMID: 27469420

4. McFarland LV, Surawicz CM, Vindigni SM. Clostridium difficile infections: Epidemiology, diagnosis, and treatment. EvidenceBased Gastroenterology and Hepatology. 2019;4e:284-305.

5. Nacionalni inštitut za javno zdravje (NIJZ). [National Institute for Public Health]. Epidemiološko spremljanje nalezljivih bolezni v Sloveniji v letu 2017. [Report on infectious disease surveillance in Slovenia for the year 2017]. Ljubljana: NIJZ; 2018. Slovenian. Available from: https://www.nijz.si/sites/ www.nijz.si/files/uploaded/epidemiolosko_spremljanje_nb_v sloveniji_2017_november2018_1.pdf

6. Nacionalni inštitut za javno zdravje (NIJZ). [National Institute for Public Health]. Epidemiološko spremljanje nalezljivih bolezni v Sloveniji v letu 2015. [Report on infectious disease surveillance in Slovenia for the year 2015]. Ljubljana: NIJZ; 2016. Slovenian. Available from: http://www.nijz.si/sites/ www.nijz.si/files/datoteke/epidemiolosko_spremljanje_nb_v_ letu_2015.pdf

7. Rupnik M. Is Clostridium difficile-associated infection a potentially zoonotic and foodborne disease? Clin Microbiol Infect. 2007;13(5):457-9. https://doi.org/10.1111/j.14690691.2007.01687.x PMID: 17331126

8. Rodriguez-Palacios A, Borgmann S, Kline TR, LeJeune JT. Clostridium difficile in foods and animals: history and measures to reduce exposure. Anim Health Res Rev. 2013;14(1):11-29. https://doi.org/10.1017/S1466252312000229 PMID: 23324529

9. Brown AWW, Wilson RB. Clostridium difficile colitis and zoonotic origins-a narrative review. Gastroenterol Rep (Oxf). 2018;6(3):157-66. https://doi.org/10.1093/gastro/goyo16 PMID: 30151199

10. Rodriguez Diaz C, Seyboldt C, Rupnik M. Non-human C. difficile reservoirs and sources: animals, food, environment. Adv Exp Med Biol. 2018;1050:227-43. https://doi.org/10.1007/978-3319-72799-8_13 PMID: 29383672

11. Candel-Pérez C, Ros-Berruezo G, Martínez-Graciá C. A review of Clostridioides [Clostridium] difficile occurrence through the food chain. Food Microbiol. 2019;77:118-29. https://doi. org/10.1016/j.fm.2018.08.012 PMID: 30297042

12. Knetsch CW, Connor TR, Mutreja A, van Dorp SM, Sanders IM, Browne HP, et al. Whole genome sequencing reveals potential spread of Clostridium difficile between humans and farm animals in the Netherlands, 2002 to 2011. Euro Surveill. 2014;19(45):20954. https://doi.org/10.2807/1560-7917. ES2014.19.45.20954 PMID: 25411691

13. Knight DR, Squire MM, Collins DA, Riley TV. Genome analysis of Clostridium difficile PCR Ribotype 014 Lineage in Australian pigs and humans reveals a diverse genetic repertoire and signatures of long-range interspecies transmission. Front Microbiol. 2017;7:2138. https://doi.org/10.3389/ fmicb.2016.02138 PMID: 28123380

14. Knetsch CW, Kumar N, Forster SC, Connor TR, Browne HP, Harmanus C, et al. Zoonotic transfer of Clostridium difficile harboring antimicrobial resistance between farm animals and humans. J Clin Microbiol. 2018;56(3):e01384-17. PMID: 29237792

15. Knight DR, Riley TV. Genomic delineation of zoonotic origins of Clostridium difficile. Front Public Health. 2019;7:164. https:// doi.org/10.3389/fpubh.2019.00164 PMID: 31281807

16. Romano V, Pasquale V, Lemee L, El Meouche I, Pestel-Caron $\mathrm{M}$, Capuano F, et al. Clostridioides difficile in the environment, food, animals and humans in southern Italy: Occurrence and genetic relatedness. Comp Immunol Microbiol Infect Dis. 2018;59:41-6. https://doi.org/10.1016/j.cimid.2018.08.006 PMID: 30290886

17. Rodriguez C, Taminiau B, Van Broeck J, Delmée M, Daube G. Clostridium difficile in food and animals: A comprehensive review. Adv Exp Med Biol. 2016;932:65-92. https://doi. org/10.1007/5584_2016_27 PMID: 27350639

18. Pasquale V, Romano VJ, Rupnik M, Dumontet S, Cižnár I, Aliberti $F$, et al. Isolation and characterization of Clostridium difficile from shellfish and marine environments. Folia Microbiol (Praha). 2011;56(5):431-7. https://doi.org/10.1007/ S12223-011-0068-3 PMID: 21901293

19. Pasquale V, Romano V, Rupnik M, Capuano F, Bove D, Aliberti $\mathrm{F}$, et al. Occurrence of toxigenic Clostridium difficile in edible bivalve molluscs. Food Microbiol. 2012;31(2):309-12. https:// doi.org/10.1016/j.fm.2012.03.001 PMID: 22608238

20. Lim SC, Foster NF, Elliott B, Riley TV. High prevalence of Clostridium difficile on retail root vegetables, Western Australia. J Appl Microbiol. 2018;124(2):585-90. https://doi. org/10.1111/jam.13653 PMID: 29193458

21. Tkalec V, Janezic S, Skok B, Simonic T, Mesaric S, Vrabic T, et al. High Clostridium difficile contamination rates of domestic and imported potatoes compared to some other vegetables in Slovenia. Food Microbiol. 2019;78:194-200. https://doi. org/10.1016/j.fm.2018.10.017 PMID: 30497603

22. European Commission. Regulation (EC) No $853 / 2004$ of the European Parliament and of the Council of 29 April 2004 laying down specific hygiene rules for food of animal origin. 30.4.2004: L 139. [Accessed 17 Apr 2020]. Available from: http://data.europa.eu/eli/reg/2004/853/2014-06-01

23. Biasizzo M, Vadnjal S, Henigman U, Krizman M, Kirbis A Jamnikar-Ciglenecki U. Development and validation of a new protocol for detecting and recovering Clostridium difficile from meat samples. J Food Prot. 2018;81(4):561-8. https://doi. org/10.4315/0362-028X.JFP-17-354 PMID: 29517350

24. Best EL, Fawley WN, Parnell P, Wilcox MH. The potential for airborne dispersal of Clostridium difficile from symptomatic patients. Clin Infect Dis. 2010;50(11):1450-7. https://doi. org/10.1086/652648 PMID: 20415567

25. Rupnik M. Clostridium difficile toxinotyping. Methods Mol Biol. 2010;646:67-76. https://doi.org/10.1007/978-1-60327-365-7-5 PMID: 20597003

26. Janezic S. Direct PCR-Ribotyping of Clostridium difficile. Methods Mol Biol. 2016;1476:15-21. https://doi. org/10.1007/978-1-4939-6361-4_2 PMID: 27507330

27. Rodriguez-Palacios A, Staempfli HR, Duffield T, Weese JS. Clostridium difficile in retail ground meat, Canada. Emerg Infect Dis. 2007;13(3):485-7. https://doi.org/10.3201/ eid1303.060988 PMID: 17552108

28. Songer JG, Trinh HT, Killgore GE, Thompson AD, McDonald LC, Limbago BM. Clostridium difficile in retail meat products, USA, 2007. Emerg Infect Dis. 2009;15(5):819-21. https://doi. org/10.3201/eid1505.081071 PMID: 19402980

29. Warriner K, Xu C, Habash M, Sultan S, Weese SJ. Dissemination of Clostridium difficile in food and the environment: Significant sources of $C$. difficile community-acquired infection? J Appl Microbiol. 2017;122(3):542-53. https://doi.org/10.1111/ jam.13338 PMID: 27813268

30. Indra A, Lassnig H, Baliko N, Much P, Fiedler A, Huhulescu S, et al. Clostridium difficile: a new zoonotic agent? Wien Klin Wochenschr. 2009;121(3-4):91-5. https://doi.org/10.1007/ S00508-008-1127-x PMID: 19280132

31. Hoffer E, Haechler H, Frei R, Stephan R. Low occurrence of Clostridium difficile in fecal samples of healthy calves and pigs at slaughter and in minced meat in Switzerland. J Food Prot. 2010;73(5):973-5. https://doi.org/10.4315/0362-028X-73.5.973 PMID: 20501051

32. Von Abercron SM, Karlsson F, Wigh GT, Wierup M, Krovacek $\mathrm{K}$. Low occurrence of Clostridium difficile in retail ground meat in Sweden. J Food Prot. 2009;72(8):1732-4. https://doi. org/10.4315/0362-028X-72.8.1732 PMID: 19722410

33. Bakri MM, Brown DJ, Butcher JP, Sutherland AD. Clostridium difficile in ready-to-eat salads, Scotland. Emerg Infect Dis. 2009;15(5):817-8. https://doi.org/10.3201/eid1505.081186 PMID: 19402979

34. Metcalf DS, Costa MC, Dew WM, Weese JS. Clostridium difficile in vegetables, Canada. Lett Appl Microbiol. 2010;51(5):6002. https://doi.org/10.1111/j.1472-765X.2010.02933.x PMID: 21069911

35. Eckert C, Burghoffer B, Barbut F. Contamination of readyto-eat raw vegetables with Clostridium difficile in France. J Med Microbiol. 2013;62(9):1435-8. https://doi.org/10.1099/ jmm.0.056358-0 PMID: 23449876

36. Eckert C, Burghoffer B, Barbut F. Contamination of readyto-eat raw vegetables with Clostridium difficile in France. Med Microbiol. 2013;62(9):1435-8. https://doi.org/10.1099/ jmm.0.056358-o PMID: 23449876

37. Harvey RB, Norman KN, Andrews K, Hume ME, Scanlan CM, Callaway TR, et al. Clostridium difficile in poultry and poultry meat. Foodborne Pathog Dis. 2011;8(12):1321-3. https://doi. org/10.1089/fpd.2011.0936 PMID: 21877928

38. Weese JS, Reid-Smith RJ, Avery BP, Rousseau J. Detection and characterization of Clostridium difficile in retail chicken. Lett Appl Microbiol. 2010;50(4):362-5. https://doi.org/10.1111/ j.1472-765X.2010.02802.x PMID: 20102510

39. Atidégla SC, Huat J, Agbossou EK, Saint-Macary H, Glèlè Kakai R. Vegetable Contamination by the Fecal Bacteria of Poultry Manure: Case Study of Gardening Sites in Southern 
Benin. Int J Food Sci. 2016;2016:4767453. https://doi. org/10.1155/2016/4767453 PMID: 27069914

40. Janezic S, Potocnik M, Zidaric V, Rupnik M. Highly divergent Clostridium difficile strains isolated from the environment. PLoS One. 2016;11(11):e0167101. https://doi.org/10.1371/ journal.pone.0167101 PMID: 27880843

41. Weese JS, Avery BP, Rousseau J, Reid-Smith RJ. Detection and enumeration of Clostridium difficile spores in retail beef and pork. Appl Environ Microbiol. 2009;75(15):5009-11. https://doi. org/10.1128/AEM.00480-09 PMID: 19525267

\section{License, supplementary material and copyright}

This is an open-access article distributed under the terms of the Creative Commons Attribution (CC BY 4.0) Licence. You may share and adapt the material, but must give appropriate credit to the source, provide a link to the licence and indicate if changes were made.

Any supplementary material referenced in the article can be found in the online version.

This article is copyright of the authors or their affiliated institutions, 2020. 